\title{
Rights And Treatment Of Prisoners Of War Under Islamic International Humanitarian Law: A Legal Analysis
}

\author{
Ibrahim Abdullahi \\ (FRHD), LL.B, BL, LLM, PhD. \\ Faculty of Law, Department of Private and Business Law, \\ Usmanu DanFodiyo University, Sokoto.
}

\begin{abstract}
The central thrust of this paper is on the legal analysis of the rights and treatment of prisoners of war under Islamic International Humanitarian law. Islamic Law as a complete system of law has corresponding rules regulating the treatment of prisoners of war and imbibed therein is the elementary considerations of humanity. This paper makes use of the doctrinal methodology in making legal analysis of the Rights and Treatment of Prisoners of War under Islamic International Humanitarian and in so doing, making cross references with the International Humanitarian Laws of the Geneva Conventions. The paper concludes that the fundamental rules and principles relating to the rights of prisoners of war under Islamic Law show striking similarities with that of the Geneva Conventions. However, issues of maltreatment of persons detained in armed conflicts as well as lack of political will by belligerents to respect and prevent violation of International Humanitarian Law (IHL) are increasingly common area of concern to the extent that Islamic laws and norms relating to the rights and treatment of prisoners of war is a better alternative to conventional International Humanitarian Laws and can be used as a model for improving the contemporary International Legal Regime
\end{abstract}

Key Words: Islamic Law, International Humanitarian Law, Prisoners of War and Jihad

\section{INTRODUCTION}

This paper focuses on making a legal analysis of the Rights and Treatment of Prisoners of War under Islamic International Humanitarian Law. War is a part of life. If a war is just, not for the purpose of bruit conquest and imperial expression, nor for aggression and hatred, then such a war has a positive role to play in preserving civilization and removing from it the blights that seek to bring it down. Just and legitimate warfare is a necessity in order to resist aggression and oppression, to defend against enemies, and to overcome those who oppress the truth and forcibly keep people from it.

As Islam stands against waging war, especially against the innocents, it never overlooks the possibility that mankind may resort to war against each other. That is why it shows keenness on regulating warfare between parties and not only that, but also setting rules regarding those taken as prisoners of wars. Islam does not allow any form of abuse whether it is physical or sexual. On the contrary, the Islamic texts have preceded the Geneva Conventions in all ramifications relating to how hostilities are to be concluded.

In this paper, a discussion would be made of the rules of Islamic law relating to issues bordering on Jihad, Prisoners of War under the 3rd Geneva Convention on the Protection of Prisoners of War,, Classification of Prisoners of War, Classification and Punishments for Prisoners of War and comparative analysis will be made on the benefits for Prisoners of War under Islamic Law and the 3rd Geneva Convention 1949 before drawing conclusions 
Since prisoners of war are a product of war, it is apt at this point to consider albeit in brief the meaning, scope and restraint relating to the conduct of Jihad under Islamic International Humanitarian Law.

\section{MEANING AND SCOPE OF JIHAD UNDER ISLAMIC LAW}

The word "Jihad" is derived from the basic root "g _ $h_{-} d$ ", which means struggle or endeavor.1 Therefore Jihad means to strive hard; to forbear hardships for a great cause. In the lexicon of Islam, the term jihad has two meanings, one narrower and the other much wider. In its widest sense, it covers every activity and struggle for making the word of God Supreme. It even includes one's effort for purification of his soul, Mujahadah. In a sense, it also includes striving hard to find out and ascertain the intent of the law giver.

In its narrow sense, Jihad is use in the meaning of war i.e. war for the purpose of making the war of God supreme.

The terms Ghazwah denotes the war in which the Prophet personally took part and Sirah literally means conduct, but technically denotes biography of the Prophet or his conduct. The books that dealt with the Islamic Jus ad bellum and Jus in bello were given the names Siyar because these rules were based on the Prophets conduct during the wars against his opponents and the earlier treaties on war were called Maghazi.

Majority of the Muslim jurists are of the opinion that the cause of Jihad or war contrary to what is largely believed is not Kufr (disbelief) but Muharabah (aggression).2 Thence, mere disbelief in Islam does not of itself legalize killing. Rather it is Muharabah (aggression) that makes it permissible to kill the Muharib (aggressor). This is why; it is not allowed to kill women, children, and people of old age, handicapped and other who do not have capacity to fight. This is indeed similar to the position under the Geneva Conventions in our contemporary era.

If therefore Kufr (disbelief) is the cause (Qital) of jihad, it is argued that Islamic Law would not have given protection to non Muslims citizen of Islamic state and it would have amounted to compulsion in matters of religion and thus violating the Quranic injunction: "There is no compulsion in matters of religion.3 So Muslims are only entitled to fight only those who commit aggression against them. Sarakhsi4, one of the great Jurists of all times states:

"The purpose of the obligation of Jihad is to protect Muslim from their opponent so that they may be able to live good worldly life in accordance with their religion."

\footnotetext{
1 Ibn ManzuriLisan Al Arab,,Cairo. Dar al Hadith Vol. 2, (2003), P 240 - 241; Hans Wehr, A Dictionary of Modern Writter Arabic, (1974) London; Macdonald and Evans Ltd, P. 233.

2Ibin at - Humam, Fath al - Qadir Vol. 4 P.291; SahnunAbdal - Salam. B. Sai'd al Taankhi, Al - Mudawwanah al Kubra(Damaan: Dar Al Fikr (1966) Vol. 3 P. 6: Some of the Shafi'i and Hanbali considered Kufr (disbelief in Islam) to be the cause of Jihad.

${ }^{3}$ Qur'an 2:256. See for secularly analysis of the issue; Muhammad Munir, Public International law and Islamic International Law: Identical Expression of World Order Faculty of Shariah and Law, International Islamic University Islamabad, 372.

${ }^{4}$ AbuBakarMuhammed. B. AbiSahl al - Sarakhsi was one of the must renowned Hanafi Jurists.

5Sarakhsi A.B. Al - Mabsut(Beirut: Daral. Ma'rifah (1978) Vol. 10 P. 28.
} 


\section{Restraints in the Conduct of Hostilities under Islamic International Humanitarian Law Inviolability of the Civilian Population and Property.}

Parties to a conflict must at all times distinguish between civilian and combatants and must not be directed against civilians. Acts or threats of violence where primary purpose is to spread terror among the civilian population are prohibited. Civilians here refer to persons who are not members of the armed forces and civilian population comprises of all persons who are civilians and are protected against attack, unless and for such times as they take part in hostilities.

Civilian object encompass all objects that are not military objectives. They are protected against attack, unless and for such time as they are military objectives. These indiscriminate attacks 6 are prohibited. The principle of proportionality must be observed in the conduct of hostilities in armed conflicts 7 and that the parties must also adhere to international humanitarian law rules governing precautions in attack or against the effect of attacks. 8 Prohibited weapons are not to be used.

The general IHL rule that civilians are entitled to protection against the danger arising from military operations9 is thus modified if they directly participate in hostilities. IHL expressly provides that civilian are protected from direct attack - meaning that they may not be targeted unless and for such time as they take a direct part in hostilities.10

As opposed to combatants who may not be prosecuted by the capturing state for direct participation in hostilities (combatants privilege), civilian who take a direct part in hostilities may be prosecuted for having taken up arms and full acts of violence committed during both participation by the detaining state as well as, of course, for any war crimes or other crimes under international law committed. This rule is the same in both international Armed Conflict IAC's and Non-International Armed Conflict NAIC's. Civilian direct participation may be prosecuted under domestic law when it does not constitute a violation of IHL and is not a war crime parse under a treaty or customary IHL.11

\section{PROTECTION OF THE VICTIMS (NON COMBATANTS)}

Members of the armed forces and other persons who are wounded or sick are to be respected and protected in all circumstances. They are to be treated humanely and cared for by the party to the conflict in whose power they may be without any distinction founded on sex, race, nationality, religion, political opinions, or any other similar criteria. Any attempt upon their lives or violence to their person, shall be strictly prohibited. In particular, they are not to be murdered or exterminated nor subjected to torture or to biological experiments or willfully left

\footnotetext{
${ }^{6}$ Indiscriminate attack are those (a) which are not directed at a specific military objective; (b) which employ a method or means of combat which cannot be directed at a specific military objective; or (c) which employ a method on means of combat the effects of which cannot be limited as required by intentional humanitarian law; and consequently, in each such case, are of a nature to strike military objective and civilian objects without distinction.

${ }^{7}$ Launching of an attack which may be expected to cause incidental loss to civilian life, injury to civilian, damage to civilian objects or a combination thereof would be excessive in relation to the concrete and direct military advantage anticipated, is prohibited.

8 Customary law study, Rules $15-24$.

${ }^{9}$ Art 51(1) AP 1.

10 Art 51(3) AP1, Art 13(3) AP II.

11 See, for example, the list of war crimes under Article 8 of the ICC Statutes.
} 
without any medical assistance and cure or be exposed to conditions contagious or infectious to them. ${ }^{12}$

To close any loopholes, Additional Protocol 1 contains an extensive provision on the treatment of persons in the power of a party to the conflict. ${ }^{13}$

Article 75 of the Additional Protocol 1 therefore constitutes a "safety net for human right" that is of inestimable value for their reason. It is of special interest, forming as it does the link between protection of human beings through international humanitarian law and the guarantees contained in human rights treaties. Since 1977 the "hardcore of human rights" has been more or less uniformly defined in the laws applying to war and peace.

Under Islamic law, the starting point of Islamic injunction relating to non - combatant's immunity is the verse of the Quran ${ }^{14}$ which states:

"Fight in the way of Allah against those who fight you, but do not commit transgression lo! Allah loveth not transgressors.

Some Muslim jurists argue that the command "do not commit transgression" implies that Muslims should not initiate hostilities. ${ }^{15}$

Some other jurist argues that this command also includes prohibition of mutilation of the dead bodies of the enemy soldiers and maltreatment of the prisoners of war. ${ }^{16}$ Some others Muslim Jurist ${ }^{17}$ believed that the command also implies that Muslims should refrain from killing those who are not capable of fighting such as women, children old people, monks and other noncombatants. They relied on two grounds for their argument. Firstly, the word that occurs on the verse "Fight" which implies conflict between two or more people who activity engage in strife and not between one who is a combatant and one who is not a non - combatant.

Bukhari reports on the authority of Ibn Umar that at the time of the conquest of Mecca, when the Holy Prophet (SAW) found the dead body of woman in the battle field, he exclaimed, "Why was she killed? She was not fighting!" then he prohibited the killing of women and children. ${ }^{18}$ Several other companions reported that the Prophet would not kill woman and children in wars and he prohibits his companion from killing women and children. ${ }^{19}$

The famous tradition about the Holy Prophets (SAW) commandment to his commanders which form the basis of Islamic Jus in bello amongst others states:

\footnotetext{
12 See paragraph 1 to 4 of Art 12 of the $1^{\text {st }}$ Geneva Convention Article 72 of the $2^{\text {nd }}$ Geneva Convention relating to prisoners of war and Article 22 of the fourth Geneva Convention relating to civilian are similarly worded.

13 See Article 75 of Section III entitled "Fundamental guarantees" reads like a condensed version of the Declaration of Human Rights, specifically framed for conditions of war. It represents a minimum provision which is subordinate to the more extensive guarantee contained in the individual Geneva Convention or in human rights treaties.

14 Q. 2:190.

15 Ibid.

16 The Interpretation is upheld by Sa'ib .b. Jibayr, Abdul Aliyah and Abu - al - Hassan al - Bairi in their works Non Combatant Immunity P.2..

17These Include Abdullah b. Abbas, the Prophet cousin whom the Prophet gave the title, "The interpreter of the Quran", his disciple Mujahid and Umar b. Abd - al - Aziz "the fifth righty - guided caliph".

18 See Bukhari, Kitab al Jihad, Hadith No. 2791.

19 Muslim reports this prohibition from Ibn Abbas, Abu Dawud and Ibn Majah. See equally Bukhari Kitab al Jihad, Hadith No. 3377, 2295 and 2832.
} 
“...Do not break your pledge, do not mutilate (dead bodies) and do not kill the children..." ${ }^{\prime 20}$

The Commandment of the successor of the Holy Prophet (SAW) such as Abu Bakr, was reported to have instructed the commander of his troops in the following manner:

"I enjoin upon you ten injunctions. Remember these: Do not embezzle. Do not Cheat, Do not break trust. Do not mutilate, Do not kill a child or an old man or a woman, Do not hew down a date, palm or burn it, Do not cut down a fruit tree, Do not slaughter a goat or cow or camel except for food... Maybe, you will pass near a people who have secluded themselves in convents; leave them and their seclusion" 21

Umar, Uthman and Ali Khalid. B. Al Walid, the famous General of Islam was also reported to have given the same instruction to their subordinates. ${ }^{22}$

The reason for the exclusion of women, children, peasants and tradesmen was their non combatant status. By way of Qiyas (analogy) in Islamic Jurisprudence, the rule can be extended to all classes of non combatants. Thus Islamic law did not confine itself to enumerating the kinds of non - combatants who are immune but by analogy this will apply to everyone who does not take part in war. ${ }^{23}$ The majority of the jurists believes in the immunity of all those who do not take part in combat. ${ }^{24}$ But they proved this immunity in different ways on the basis of their theories of interpretation.

The general command in the Quran which reads:

"Then, when the sacred months have passed, slay the idolaters wherever ye find them, and take them (captive), and besiege them, and prepare for them each ambush. ${ }^{25}$

has been qualified by the next verse which reads:

"And if anyone of the idolators seekth thy protection, then protect him so that he may hear the word of Allah; and afterwards convey him to his place of safety. This is because they are a folk who know not. ${ }^{26}$

The above verse therefore gives immunity to a class of non - Muslim; those seek protection from the Muslims. The conclusion of the Muslim jurist is that all classes of non combatants enjoy immunity from the effects of war.

\footnotetext{
20 This tradition have been reported by several traditionalists from a number of companion that include "Abdullah .b. Mashud, Anas. B Malik, Samurah, Ya'la, Buraydah, Shaddad, Imran and Abu Ayyub. See Ghazi, Mahmood Ahmed (1998), Chapter on "Muslim International Law" with original text of Al - Siyar - Al - saghir (Islamabad Islamic Research Institution, P1 of the Arabic text and P.43 of the English Translation.

${ }^{21}$ See Al - Tabiri, Ta'rikh al - Umam wa - al - muluk, Beiruit: Dar Ihya'al - Turath al - Arabi, (1994) Vol. 3 Pp. 849 $-50$.

${ }^{22}$ For details see Al - Juwayni, Abdal - Malik .b. Abdullah (2002), Usul Fiqh, Beirut; Dar' Ihya al - Turath al Arabi, Vol. Pp 28 - 76.

23 Al- Zuhayli Wahbah, Athar al - Harb P. 74.

24 Ibn Hazim, Ali .b. Ahmad (1934), Al Muhalla bi al - Athar, (Cairo: Idarat al - Taba'ah al Muninyah), Vol. 7 P. 296 297.

25 Q 9:5.

${ }^{26} \mathrm{Q} 9: 6$.
} 


\section{Loss of Immunity of Non - Combatants}

When individual take part or assist in actual combat, they lose their status of being non combatants and become one of the aggressors. Hence it becomes legitimate to kill them during combat. In an age when there were no organized enemies, every adult male member of the community would take part in combat and hence would be considered a potential, if not actual, combatant.

On the other hand, women, children and the old though potentially non - combatants would be considered combatants only when they take part in actual combat. In modern time, however, every state has an organized and well trained army. Hence the presumption under Islamic Law about all civilian male and female is that they do not take part in combat. ${ }^{27}$

The second instance in which civilian and non - combatants lose immunity is that of duress. Thus, the Prophet allowed night raids (necessity) on enemy even if there was a possibility that women and children could become targeted because they were in close vicinity to the combatants. ${ }^{28}$ But again, "necessity" should be kept within its limits.

Muslim jurist have generally agreed on the issue that if the enemy uses non - combatant as a human shield to protect themselves and attack Muslims, then the non - combatants can be killed in the combat, even though these are Muslim women, children and prisoners of war. Then killing is allowed under the principle of necessity. ${ }^{29}$ Muslim jurists further unanimously agree that there will be no compensation in material terms for the killing of non - combatant in such a situation. ${ }^{30}$

\section{PRISONERS OF WAR UNDER THE CONVENTIONAL INTERNATIONAL HUMANITARIAN LAW}

The Prisoners of War Convention of 1929 had already ensured that it was forbidden to take measures of reprisals against prisoners of war. The Third Geneva Convention relating to the treatment of prisoners of war deals extensively with the plight of those taken captive in war, declaring that "Prisoner of war will at all times be treated humanely"31 Prisoners of wars (POWs) are members of the armed forces of one of the parties to the conflict who fall with the hands of the adversary during an international armed conflict. They retain their legal status as members of the armed forces during their captivity an indicated externally by the fact that they are allowed to wear their uniforms, that they continue to be subordinate to their own officers who are themselves prisoners of war and that at the end of hostilities they have to be returned to their own country without delay. It is moreover, explicitly stated that prisoners of war are not in the hands of individuals or military units, but are in the care of the adverse state, since it is the state, as a party to the Geneva Convention that is responsible for fulfilling its international obligation..$^{32}$ Being a prisoner of war is in no way a form of punishment. Other categories of persons listed in the third Geneva Convention as having the same status as

\footnotetext{
27 See Munir, Non Combatant Immunity op cit, P. 48.

28 Muslim Kitab Al - Jihad Hadith No. 432.

${ }^{29}$ Mushtaq, Use of force for the Right of Self Determination. 179. Dr. Hamidullah says "it appears that in classical times of Islam, it was a present practice among non - Muslim to take shelter behind enemy prisoners. I have not found a single instance where they force their prisoners to fight against their notion.

30 See Al - Zuhayli Wahbahi Alfigh al - Islam Wu Addilatuhu. (Damascus: Dar al Fikr) 1984. Vol 6 P. 424 . See also Art. 51 (7) of Additional Protocols 1 to the Geneva Convention relating to the protection of victims of International Armed Conflicts.

31 Third Geneva Convention, Article 13.

32 Ibid, Article 12.
} 
members of the armed forces include members of a resistance movement belonging to a party to the conflict who satisfy the following four requirements;

(i) They must be commanded by a person responsible for his subordinates;

(ii) They must have a fixed distinctive sign which is recognizable at a distance (if they have no uniform of their own);

(iii) They must carry arms openly;

(iv) They must respect the law and customs of war. ${ }^{33}$

Certain persons authorized to accompany the armed forces without belonging to them such as civilian members of ship and aircraft crew, war correspondents, though not those journalists who are to be treated as civilians under the rules of Protocol 1 are also to be treated as prisoners of war. $^{34}$

Also entitled to be treated as prisoners of war are members of the population who spontaneously take up arms to resist approaching enemy forces (Levee en masse). If however, there is any doubt about the status of a captured person, such doubt must be cleared up by a competent tribunal. ${ }^{35}$

The Third Convention also known as "The POW'S Convention" regulates to the smallest detail the treatment of prisoners of war. ${ }^{36}$ Besides, the repatriation of prisoners of war is adequately provided for. The following three categories are however distinguished;

(i) The severely wounded and sick must be repatriated directly and without any delay i.e. as soon as they are fit to travel. It is the duty of the mixed medical commissions to decide who will be repatriated. ${ }^{37}$ ICRC delegation posses however, the necessary experience to carry out such repatriations at any time.

(ii) All prisoners of war must be released and repatriated without delay after the cessation of active hostilities. ${ }^{38}$

(iii) The parties to the conflict should, without waiting for the war to end, repatriate prisoners of war on humanitarian grounds, possibly on a reciprocal basis i.e. by means of an exchange of prisoners. ICRC constantly tries to bring such agreements about. As a neutral intermediary between the parties, ICRC is always prepared to carryout repatriation and exchanges of prisoner of wars (POW's).

In accord with Article 118 of the Third Convention, prisoners of war cannot refuse repatriation to their own country and they must be so repatriated. However, in case of difficulty, when POWs refuse to be repatriated as happened during the Korean War, it is the role of the ICRC to determine objectively each prisoner will. In this respect, ICRC take part in the repatriation of POW's only if its delegates have really been able to verify that each prisoner's decision was freely made. Unjustifiable delay in the repatriation of prisoners of war is a grave breach of Protocol $1,{ }^{39}$ while release of a prisoner of war in parole is regarded as a chivalrous conduct. ${ }^{40}$

\footnotetext{
33 Ibid, Article 4 A (2).

${ }^{34} \mathrm{Ibid}$, Article 4 A (4) and (5).

35 Ibid, Article 5 paragraph 2.

36 For details see, Third Geneva Convention, Article 21 - 108. See also for a brief summary of such detailed regulations, Hans Peter Gasser op cit Pp 33 - 38.

37 Third Convention, Article 112.

38 Ibid, Article 118.

39 Protocol 1, Article 85.4(b).

40 Third Convention, Article 21, paragraph 2.
} 
In accordance with this custom, instead of being interned, ${ }^{41}$ POW's may be freed on parole by the detaining power and sent back to their own country, as condition that they have solemnly sworn no longer to take part in the fighting against the state that had captured them. Internment was therefore not practiced under classical Islamic Law; instead, enslaved people live with their new masters who took care of them. Detaining captives (after decision on options) is therefore private and not a state affair which is a measure departure from IHL.

\section{CLASSIFICATION OF PRISONERS OF WAR UNDER ISLAMIC INTERNATIONAL HUMANITARIAN LAW}

Under Islamic Law, Prisoners of War (war captives) are divided in the manual of Figh into 3 categories namely;

1. Asra (POW's): People captured while they were taking part in actual combat. In other words, they are enemy combatants.

2. Saby: Women and Children of the enemies.

3. Ajazah: Older and disable people. Hermits, Monks and priest are also included in this category.

The general principle of Islamic law is that Prisoners of War (war captives) must be treated humanely. The Glorious Quran states the qualities of a righteous Muslim as follows:

"And (they) feed with food the needy, wretch, the orphan and the captive, for love of him, (saying); we feed you, for the sake of Allah only. We wish for no reward nor thanks from you: Lo! We fear our Lord a day of frowning and of fate. $^{42}$

The Holy Prophet (SAW) on the victory of Mecca gave these following imperatives:

"Do not attack the injured person: Do not follow the one who leaves the battle field: and do not kill anyone who is captured". ${ }^{43}$

Various Prophetic traditions emphasized good and human treatment of prisoners of wars. ${ }^{44}$ Islamic Law allows preference in treatment and prohibits humiliation of the noble in aftermaths of war. This may depart from IHL in non-discrimination among captives but may agree with IHL in kind treatment based on POW status based on rank. In classical Islamic law, there was absence of unnecessary procedures for captives and things happen within minutes; there was no need to count, classify, debrief, etc and so it should be under IHL.

\footnotetext{
${ }^{41}$ Internment is defined as the deprivation of liberty of a person that has been ordered by the executive branch not the judiciary without criminal charges being brought against the internee. See commentary on Additional Protocols of $8^{\text {th }}$ June 1977 to the Geneva Convention of $12^{\text {th }}$ August 1949, ICRC/Martinus Njihoff publishers, Geneva 1987, commentary on Additional Protocol 1 Art 75(3) Para, 3063. Under IHL applicable international armed conflict, internment (and assigned resident) is the most severe measure of control that a detaining authority may take with respect to person against whom no criminal proceedings are instituted. See Pejic J, "Procedural principles and safeguards for internment/administrative detention in armed conflict and other situations of violence" published as Annex 1 to the ICRC's Report on "International Humanitarian law and the Challenges of contemporary armed conflict", presented to the $30^{\text {th }}$ International Conference of the Red Cross and Red Crescent held in Geneva in 2007. It is also prohibited in International Review of the Red Cross, Vol. 87 No. 858, June 2005, Pp 375 - 391. Also available at http://www.icrc.org/eng/assets/files/other/irrc-858-pejic.pdf. (Last visited on 5th April 2012).

${ }^{42}$ Q. 76: $8-10$.

${ }^{43}$ Al Baladhar, Futuh al - Buldan (Cairo Maktabat al - Misriyah) 1957, P. 47.

${ }^{44}$ Muslim Kitab al - Nadhr, Hadith No. 3099. See also Ibn Hisham: Abdl malik, Sirah al - Nabawiyah, Beirut: Dar al Kutub al - Islamiyyah 1994 Vol. P. 215 - 17.
} 


\section{RIGHTS OF PRISONERS OF WAR UNDER ISLAMIC LAW}

The following rights inures in favour of Prisoners of War viz;

1. Rights during Arrest: When an enemy is captured, he should be informed of the reason of his capture (especially if not in the heat of battle and in the case of spies and allies). Right to be informed agrees with IHL.

2. A Prisoner of war has the right to remain in his religion and cannot be compelled to give it up. Today this principle refers to as freedom of religion.

3. Right to nourishment enough to make his health. Denying nourishment to the prisoner of war is counted as a major sin in Islam. Since a prisoner cannot provide for himself, it is incumbent upon his captor to provide for him since Islam places the needs of a prisoner of war on the same level as the needs of the poor and the orphan. Even though this is not a feature in the classical times because medicine was not advanced then, but nowadays, it's a necessity. It is prohibited to finish up a wounded enemy. Helping him is part of kindness.

4. He has a right to be clothed in dignity in a manner that is appropriate to his body station. It was reported that after the battle of $B a d r$, prisoners of war were brought among them was $\mathrm{Al}$ - Abbas. He did not have a shirt on, so the Prophet (Peace be upon him) looked for a shirt for him. It turned out that a shirt of Abd Allah b. Ubayy was the right size, so the Holy Prophet (SAW) gave it to $\mathrm{Al}$ - Abbas to wear and compensated Abdullah with his own shirt. 45

5. Right to decent lodgings: whether they are in a prison cell or even a private home.

6. When families are taken together as prisoners of war, they have a right not to be separated. A mother should not be separate from her child, nor should that child be separated either. The Brother should not be separated either. The Prophet (SAW) said regarding captives:

"Whoever separates a mother from her child will be separated from his own loved ones on the day of judgment"46

Therefore Islamic law prohibits separating mothers from their children until they reach age of discernment/maturity, even if the mother agrees because it will harm the child.

7. Prisoners of war have a right not to be subjected to any abuse or torture. They cannot be abused on account of the fact that they were fighting against the Muslim. Islamic Law does not command us to punish them for this reason. Right not to be subjected to torture includes the prohibition against forcing them to sit/stand in the sun. For instance, Bani-Quraizahh, after defeat was put in the sun, the Prophet saw that and ordered their release from the sun, stating that "do not combine the heat of the sword (the just ended battle) and the heat of the sun. Islamic Law therefore agrees with IHL on the rights of POWs not be subjected to torture or medical experimentation and the protection against acts of violence, insults and public curiosity.

8. If not during the heat of battle, executing a POW by individuals is prohibited.

9. Mutilation is strongly prohibited. Mutilation is described by Islam as changing God's creation. For instance, at the battle of Uhud, bodies of Muslims including the Prophet's uncle were mutilated by the enemy and the Prophet and his followers vowed to do the same if they got the chance. However, following this, the Qur'anic verse ${ }^{47}$ on mutilation was revealed and the Prophet in return prohibited betrayal and mutilation. This instruction was then followed by $\mathrm{Abu} \mathrm{Bakr}$ instructing follows to "beware of mutilation, because it is a sin and a disgusting act".

\footnotetext{
45 See Al - Bukhari, Hadith 3008.

${ }^{46}$ See Al - Tirmidhi (1283), Ibn Majah (2250) and Abu Dawud (2696).

47 Q16:126-127.
} 
10. Right not to be humiliated. The women that will be taken as concubines shall not be touched until after a menstrual cycle and the pregnant until after birth. The master assumes paternity thereafter.

11. Right not to be stripped off naked, even corpses shall not be left naked, especially women.

12. To be respected and accorded dignity, kindness and sympathy. To this end, the Glorious Quran ${ }^{48}$ states;

"O Prophet! Say to the captives that are in your hands: "If Allah knows any good in your hearts, He will give you something better than what has been taken from you, and He will forgive you, and Allah is Oft-Forgiving, Most Merciful"

From the above, Allah mentions that there may be captives with good in their hearts and he will give them something better than what they were deprived of. Allah will forgive captives. Thence, captives are not a different species, aliens or some other creatures, they are like anybody else and should be treated so. The verse equally presupposes an end to slavery, because liberty is what is better than captivity thus prompting the government to carry out its duty of enquiring into issues relating to POWs and or Captives and release the deserving ones.

13. Equal treatment with citizens in terms of judicial procedure and rights in remedying grievances: he can sue anybody and can be sued in civil and criminal matters; his trial will also involve the known judicial principles of proof and he has the right to look for evidence and to present it.

14. Islamic law allows captives to send messages to their families especially as this will facilitate any lobby for their release or ransom. Islamic law does not contradict the IHL position on contact and correspondence. Particularly, Islamic Law does not object to the position of International Committee of the Red Cross (ICRC) ${ }^{49}$ regarding contact between captives and their families and regarding information to the country of the captive of the captivity.

15. Captives have the right to marry for the satisfaction of their natural urge and to procreate and have progeny.

16. Captives are allowed to walk around, make friends, seek knowledge and even teach. An epitome of this was the case of the captives of Badr who had nothing to ransom themselves and their relatives were poor to present anything but were given an option that each captive teaches 10 children basic literacy for their freedom.

17. Captives are allowed to engage in businesses and their masters may agree with them on installment payments towards regaining their freedom.

The above are indeed fundament guarantees under Islamic International Humanitarian Law relating to Prisoners of War and thus Islamic Law has more elaborate provisions on this issue and the captives are more at liberty because there is no incarceration..

${ }^{48}$ Q. 8:70.

49 The International Committee of the Red Cross (ICRC) is an impartial, neutral and independent organization created to protect the lives and dignity of victims of armed conflict and other situations of violence and to provide them with assistance. 


\section{PUNISHMENTS AND BENEFITS FOR PRISONERS OF WAR UNDER ISLAMIC INTERNATIONAL HUMANITARIAN LAW AND CONVENTIONAL INTERNATIONAL HUMANITARIAN LAW}

In Islam, there is a seemingly disagreement amongst Muslim jurist of the various school of thoughts regarding the punishments of prisoners of wars (POWs) in Islam. ${ }^{50}$ Under Islamic Law, taking captives is legal in the Qur'an. The Qur'an provides:

“... And then tighten their bonds..."

By interpretation, it means that when the enemy is overpowered, the remainder (weak, trapped behind enemy lines, etc) will be captured: (tighten their bonds) which is a metaphor. After the cessation of warfare, a choice is conferred with regards those in bond. One may either act graciously towards them by setting them free without charge, or free them for a ransom that is required from them. However the factor that determines detention is the discretion of the Imam (head of state) and public policy (maslaha) plays important role in this.

Muslim jurist agree that the faith of prisoners of wars are left to the political authority to decide as he deems fit in the interest of the Muslim community. However, Muslim jurist diverge over the choices available to the Muslim state to terminate their captivity (i.e. to kill). According, to the majority of Muslim scholars, ${ }^{52}$ the political authority has the following options, execution, enslavement, Mann (unconditional release) and "fida" (ransom or release after setting a condition or demanding a promise). ${ }^{53}$ The Malikites added a further condition to this and that is imposition of Jizyah (Poll tax) on them. ${ }^{54}$

The Hanafi jurist agree on execution, enslavement and setting captives free with the condition that they should pay Jizya but there is disagreement on ransom. ${ }^{55}$

\footnotetext{
50 Secondary works on Islamic jus in bello usually give some space to the issue of POWs but such works are not comprehensive. A good work is Gerhard Conrad, Combatants and privies of war in classical Islamic law: concepts formulated by Hanafi jurist of the $12^{\text {th }}$ Century" In Revue de Droit Penal Militaire et de Droit de la Guerre, V.1 20, No's 3-4, 1981 Pp 271-307. This work is exclusively on POWS in Islam, but is not exhaustive and fails to elaborate the complex rule regarding POWS and the reasons behind the differences in opinion among early Muslim jurists. Another noteworthy study is that of Khalid Abou El-fadl (1999), "Saving and taking life in war; three modern Muslim views" In Muslim World, Vol. 89, No. 2, Pp 158-180, in which he discusses the work of three modern scholars of the twentieth century: see also Syed Sirajul Islam, "Abu Ghraib, prisoner Abuse in the light of Islamic and International law", In Intellectual Discourse, Vol. 15, No. 1, Pp. 15-19. Works based on secondary sources include Yadeh Ben Ashoor, "Islamic and International Humanitarian law" In International Review of the Red Cross, No. 722, March - April (1980) PP 1-11, especially Pp 3-7, and Troy S. Thomas (1997), "Prisoner of War in Islam: a legal Enquiry" In Muslim World Vol. 87, January, Pp 44-53. The first article briefly discusses the interpretation of Qur'anic verses regarding POSs unfortunately; the author does not give reference for many works discussed in his article. In the second work, the author has given a summary of Islamic law regarding POWs. A recent work in Arabic in Amour al Zemmali (ed), Maqalat fial-Qanun al-Duwali al-Insani wa al-Islam, $2^{\text {nd }}$ edition, ICRC 2007. This is a compilation of fifteen essays primarily published in the international Review of the Red Cross on the various aspects of Islamic jus in bello, in some cases in comparison with international humanitarian law. A comprehensive examination of the subject of war by Ameur Zammali, Combatants et prisonniers de guerre en droit islamique et en droit international humaniteure (combatants and prisoners of war in Islamic law and international humanitarian law), Pedore, Paris, 1997.

51 Q 47:4.

52 Maliki, Shafi'I, Hambali, Shi'ite, Zahirite and Anzai.

53 Muhammad Al-sharbinial khalib, Mughni al-muhtaj, Maktaba Mustafa al-Babi, Cairo 1933, Vol. 4, P. 228 : Ali b. Ahmed b. Sa'eed b. Hazin, Al-Muhalla, Dar al- Fikr, Beirut, Vol. II Pp 97-98.

54 Muhammed b. Ahmed b, Rushd, Biayat al-Mujtahid, trans limran A. K. Nyozee, Garnet publishing Ltd, 1994 and Vol. 1 P. 456; Muhammad b. Ahmed is Juzii, al Qawanin al-fiqhiyya, Dar at Kutub al-ilmiya, Beirut P. 99; Ahmad b. Idris al-Qarafi, Al-Furuq (along with Idrar al - Suruq ala Anwa al furuq) Dar al-m'rifa, Beirut nd Vol 3. P 17.

55 Alauddin Abu Bakr al-Kasani (2000), Bada'I al-Sanai, Dar Ethia al-Tourth al-Arabi, Beirut, Vol. 6 P. 94
} 
However the Qur'an mentions the fate of POW's in the Qur'an which says;

"Now when you meet (in war) those who are bent on denying the truth, smite their necks until you overcome them fully, and then tighten their bonds, but thereafter (set them free) either by an act of grace or against ransom, so that the burden of war may be lifted. Thus (shall it be). ${ }^{56}$

The above verse therefore renders execution illegal and makes captivity a temporary affair that must lead to unconditional or conditional freedom, or freedom bought with ransom. ${ }^{57}$ The political authority has the option of releasing prisoners against ransom or setting them free without any ransom. ${ }^{58}$ This is supported by the instruction of the Prophet (PBUH) that he gave while conquering Mecca thus:

“... Slay no wounded person, pursue no fugitive, execute no prisoner, and whosoever closes his door is safe"s9

Al-Hassan b. Muhammad al-Tamim. 656AH/1258CE has related that there is a consensus (ijma) of the companions that prisoners of wars shall not be executed. ${ }^{60}$

According to authentic reports, in all the wars of the Prophet (PBUH) only three to five ${ }^{61}$ POWs were executed. Thus only Ugbah b. Abi Mu it was executed out of seventy captives of Badr, ${ }^{62}$ for his crimes against the Prophet (PBUH) and Muslims in Mecca. ${ }^{63}$ The second was Abu Izzah al-Jumah in Uhd. ${ }^{64}$ The third prisoner of war was Abdullahi b. Katal, who was executed on the day that Mecca was conquered. ${ }^{65}$ All these people were executed because of the human crimes they had committed against the Islamic State before their captivity and were wanted criminals in the Islamic state (State of Medina) of which Muhammad (PBUH) was the head. It is clearly therefore never an established rule at the time of the Prophet (PBUH) that POWS be executed.

\section{Q 47:4.}

${ }^{57} \mathrm{Q}$ 8:67-68 of the Qur'an brought censure upon the prophet (PBUH) because no revelation attesting to their being lawful had been sent to him and because the companions were tempted by ransom. However as is mentioned in these verses, ransom was legalized in the following wordings: "Enjoy them, all this is lawful and good among the things which you have gained in war, and remain concern of God: verily God is much forgiving, a dispenser of grace".

58 MUNIR M, "The Layha for the Mujahideen: an analysis of the code of conduct for the Taliban fighters under Islamic Law" International Review of the Red Cross Vol. 93, No. 881 March 2011 Pg. 90.

${ }^{59}$ Abu al-Abas, Ahmad b. Jabir al-Baladhuri (1916), Kitab futuh al Buldan tras. Philip Khuri Hitti, Columbia University, New York, Vol. 1 P. 66.

${ }^{60}$ Abdul Walid Muhammad ibin Rushd (1994), The Distinguihsed Jurist Primer, trans Imran Nyazee, Reading: Garnet Publishing Ltd, Vol. 1 P 456.

61 However, the reports about the execution of al-Nair is al Hadith and one of the concubines of Abdullahi b. Khattal are less authentic.

62 It is said that al-Nadr b. al-Harith was killed in captivity. According to Ibn Kathir, al-Madr was killed during the war. See Ismail b. Umar b. Kathir (1966), Al Bidya wa'al-Nihaya, Maktaba al-Marif Riyadh, Vol. 3, P. 35.

63 Abdul Walid Muhammad Ibn Rushd, The Distinguished jurists primer op cit at P. 130.

${ }^{64} \mathrm{He}$ was set free in Badr on condition that he would stop his blasphemous poetry against Islam and not to fight the Muslims again. He broke the promise and again asked for pardon but this time he was executed. See Abu Bakr b. Ahmad al Sarkhari (2002), Kitab al-Mabsut ed, Sabir Mustafa Rabab, Dar Ihya al-Turath al-Arabi Beirut, Vol. 10 P. 26.

${ }^{65} \mathrm{He}$ was a Muslim living in medina but he killed an innocent Muslim, reverted to the pre-Islamic faith, joined the enemy and thereby committed high treason, embezzled public money, bought two concubines who would compose blasphemous poetry and starts a campaign against Islam. For the Islamic State there were many other wanted criminals, but they were all pardoned at their request. For details see Muhammad Munir (2003), "Public international Law and Islamic International Law: Identical Expression of World Order”, in Islamabad Law Review, Vol. 1 Nos. 3 and 4, P. 382. 
Under Islamic Law, contractual, Suppliers and drivers are considered servants, they do not participate in hostilities and their killing is strictly prohibited. It is reported that when the Prophet (PBUH) saw the body of a slain woman amongst the dead at the battle of Hunayn, he asked, who killed her? The companion answered, she was killed by the forces of Khalid Ibn alWalid". The prophet (PBUH) told one of them "Run to Khalid" Tell him the messenger of God forbids him to kill children, women, and servants. ${ }^{66}$

The Prophet (PBUH) is also reported to have prohibited in the strongest possible words of the Arabic language the killing of women, and servants, "Never, never kill a woman or a servant" ${ }^{67}$

Pardon is generally encouraged in Islamic Law and those who pardon are praised; the best pardon is the pardon of a POW ${ }^{68}$. IHL does not contradict this principle; Islamic law is wider and more humane.

The established practice of the Prophet (PBUH) and his successors was to set POWS free unconditionally. Such release includes those of Thumama b Athal as well as eighty Mecca's fighters. ${ }^{69}$ Similarly all the fighters of Hawazin, Hunayn, Mecca, Banu al mustala ${ }^{70}$ Banu al Anbar, Fazara and Yemen were set free unless unconditionally. Abu Bakr - the first successor of the Prophet (PBUH) released Al-Ashas b Qays (d 35AH/65CE) while Umar the second successor pardoned Hormazan (d. 23AH/643) CE) an Iranian commander. ${ }^{71}$

It is in the respect that it is argued that probably Al-Hassan b. Muhammad al-Tamimi struck a chord when he proclaimed that the companion of the Prophet (PBUH) were unanimous on the prohibition of the killing of POWs. ${ }^{72}$

Those who are not pardoned conditionally may be released based on some consideration to wit;

a. It may be prisoner swap, monies paid of other valuable thing offered.

b. It may be a (civil) service.

\footnotetext{
${ }^{66}$ Al-Tabrezi, Mishkat al-Masabih, al-Maktab al-Islam, Cairo nd. Hadith No. 3955; Ibn Mayah, Sunnan, Der Ehya AlTurah Al-Arabi, Beirut n.d., Vol. 2 P. 101. For details, see forth Muhammad Munir, "Suicide attacks and Islamic Law" in International review of the Red Cross, Vol. 90, No. 869, March 2008, P. 85, also available at http://www.ciicr.org/web/eng/siteengo.nsf/html/review-869-p71 (last visited 2nd October 2011). 67 Ibn Majah, Ibid. Vol. 2 P. 948, hadith No. 2842, 8625 and 8626. Abu Bakr al-Bashqi, al Sunnan al Kubra withel gawher al-Naqi, Dar al fikr, Beirut nd Vol. 9, P. 83.

${ }^{68} \mathrm{Q} 118 \mathrm{v} 9$.

${ }^{69}$ Muslim, Sahih, Vol. 3 P. 1442, Hadith No. 1808; Yahaya b. Sharaf and Nawawi, Sharh Sahih Muslim, Matba Mahmud Tawfiq Cairo Vol. 7 P. 463.

${ }^{70}$ It is said that the captives of mustaliq ere first distributed among the companions but later, when the prophet (PBUH) married juwayriya al Harith (d 50AH/670CE), the daughter of the leader of the tribe, the companion set the captives free.

71 Some 6,000 combatants of Hunayn were not only set free but each one of them was given a special Egyptian set of clothing as well. See Abu al-Abas Ahmad b. Jabir al Baladhuri (1924), Kitaqb futuh al Buldan Trans. Francis Clark Murgotten, Columbia University, New York, Vol. 2 P. 119 Umar also wrote to his commander to release the captives of Ahwaz and Mannadhir when there were captured. Ibid PP 112 - 114.

72 This is also the opinion of a great many classical jurist including Abdullah b Umar (d. 73AH/692CE) Al-hassan al-Basri (d. 346/957CE), Ala, Dhhak b Muzahim al-Hilali (d. 100 AH/718CE) and Ismail b. Abdulrahman, know as al-Sudi (d. 127AH/744CE) Ibn Rushd agrees with this opinion According to shi'a jurisprudence, the man has only three options, mann, fida (ransom either for money or in exchange for POWS held by the enemy) or enslavement. Shia jurists consider execution while in captivity illegal. See Najmuddin al-muhaqiq al-Hilli (2004), Sharia al Isma ed syed Sadaq al Sheraza Dar al Qari, Beirut, Vol. 1 P. 251' and Sa'ib b. Habbat al-Rawandi (1985), Fiqh al Qur;an ed al-sayad Ahmad al Hussaini, Matba'a Ayatullah, Qum, Vol 1 P. 347; Zeinuddin b. Ali al-shahid al-sani (1983), AlRawdah al-Bahiyah fi sharh al humah al-Dimashqiqah, Dar ihya al-Twath al-Arabi Beirut, Vol. 1 P. 222.
} 
c. The captives of Badr who had nothing to ransom themselves and their relatives are poor to present anything were given an option that each captive teaches 10 children basic literacy.

The Geneva Conventions/IHL may not totally agree with some of these options above.

To conclude, there are only two options regarding war captives: either grace or exchange. ${ }^{73}$

The Third Geneva Convention of 1949 on Prisoners of War adopts a similar view regarding treatment of prisoner of war by giving the detaining power the rights to prosecute a prisoner of war for acts committed prior to his captivity against the detaining powers law. ${ }^{74}$ Prisoners of war must however be released and repatriated without delay after cessation of active hostilities. $^{75}$

\section{CONCLUSION}

War is not a chess game. Almost by definition, it entails human losses, sufferings and pains. The law of international armed conflicts does forbid some modes of behaviors in both the Geneva Conventions. Similar prohibitions can equally be found under Islamic Law with a view of minimizing the losses, suffering and pains and they in fact predate the prohibitions under the Geneva Conventions with greater observance in Islamic Law. The fundamental rules and principles of international humanitarian law relating to captured combatants and or prisoners of war under Islamic Law show striking similarities with that of the Geneva Conventions. However, issues of maltreatment of persons detained in armed conflicts as well as lack of political will by belligerents to respect and prevent violation of international humanitarian law (IHL) are increasingly common area of concern to the extent that that Islamic laws and norms relating to the rights and treatment of Prisoners of war is a better alternative to Conventional international humanitarian laws which needs to be emulated. ${ }^{76}$

With the International Criminal Court's recent adventures in the Middle East and North Africa, where Shariah or Islamic Law is integrated in or has a significant influence on the legal systems of these countries, knowledge of Islamic legal tradition becomes inevitable. The ICC's potential involvement in Nigeria, for example, underscores this reality as Islamic Law on rebellion offers a comprehensive code for regulating the conduct of hostilities in non-international armed conflicts, and thus it can be used as a model for improving the contemporary International Legal Regime ${ }^{77}$.

\footnotetext{
73 This is also the opinion of some of the prominent students of the companion of the Prophet: these include $\mathrm{Al}-$ Hassan Al - Bairi, Hamiad b. Salamah, Mujahid and Muhammad .b. Sirin, Kitat Al - Amwal P. 121.

74 See Article 85

75 See Article 118 of the Third Geneva Convention 1949. See also articles 109 and 111 of the same convention.

${ }^{76} \mathrm{~A}$ number of current and recent armed conflicts have placed questions relating to the conduct of hostilities high on the agenda of legal and military debate. The time issues of targeting and the choice of weapons are the heart of the debate.

77 - Elewa M., “Badar”, International Criminal Law Review 13 (2013) 593 at 595.
} 